Letter

\title{
Epigenetic Regulation of Neuregulin-1 Tunes White Adipose Stem Cell Differentiation
}

\author{
Alyssa D. Cordero ${ }^{\dagger}$, Evan C. Callihan ${ }^{\dagger}$, Rana Said, Yasir Alowais, Emily S. Paffhausen and \\ John R. Bracht * \\ Biology Department, American University, Washington DC, 20016, USA; \\ ac1109a@student.american.edu (A.D.C.); callihan.evan@gmail.com (E.C.C.); rana.said@tufts.edu (R.S.); \\ yasserahmad@yahoo.com (Y.A.); paffhausenemily@gmail.com (E.S.P.) \\ * Correspondence: jbracht@american.edu \\ + Co-first author.
}

Received: 23 March 2020; Accepted: 4 May 2020; Published: 7 May 2020

\begin{abstract}
Expansion of subcutaneous adipose tissue by differentiation of new adipocytes has been linked to improvements in metabolic health. However, an expandability limit has been observed wherein new adipocytes cannot be produced, the existing adipocytes become enlarged (hypertrophic) and lipids spill over into ectopic sites. Inappropriate ectopic storage of these surplus lipids in liver, muscle, and visceral depots has been linked with metabolic dysfunction. Here we show that Neuregulin-1 (NRG1) serves as a regulator of adipogenic differentiation in subcutaneous primary human stem cells. We further demonstrate that DNA methylation modulates NRG1 expression in these cells, and a 3-day exposure of stem cells to a recombinant NRG1 peptide fragment is sufficient to reprogram adipogenic cellular differentiation to higher levels. These results define a novel molecular adipogenic rheostat with potential implications for the expansion of adipose tissue in vivo.
\end{abstract}

Keywords: Neuregulin-1; adipose expandability; adipocytes; metabolic syndrome; epigenetics

\section{Introduction}

Obesity, defined as having a body-mass index $\left(\mathrm{kg} / \mathrm{m}^{2}\right)$ of over 30 , affects $39.8 \%$ of adults in the United States [1], is generally associated with an increased incidence of health problems including type 2 diabetes, cardiovascular disease, and cancer [2]. Obesity is characterized by an increase in percent body fat driven by the expansion of white adipose tissues (WAT). This can occur by an increase in adipocyte size, adipocyte number, and/or accumulation of adipose tissues in differing depots [3]. These different mechanisms of adipose tissue expansion and deposition are associated with differing health outcomes. More specifically, the accumulation of adipose tissue in the visceral regions (intra-body cavity and near vital organs) is associated with an elevated risk of diabetes [4] and cardiovascular disease [5], while subcutaneous lipid storage (within depots just under the skin) is comparatively benign [6,7]. Indeed, the visceral-to-subcutaneous adiposity ratio has been proposed as a predictor of metabolic health $[8,9]$ and a study of obese individuals that transitioned from metabolically healthy to unhealthy obesity showed a corresponding increase in visceral fat [10]. Evidence has begun to accumulate suggesting that adipogenesis-differentiation of new fat cells-within subcutaneous depots is a key factor in modulating healthy versus unhealthy adipose tissue deposition. The inability of subcutaneous adipose tissue depots to differentiate new fat cells leads to enlargement of existing adipocytes (hypertrophy) and spillover of lipid into ectopic sites including the visceral depots [11-14]. Consistent with this, patients exhibiting visceral adiposity exhibit lower adipogenic potential in subcutaneous depots [15] possibly due in part to senescence of the stem cells [16], suggesting that tissue-specific adipose expandability limits are critical regulators in whole-body metabolic health. 
The adverse metabolic consequences of obesity are also due to an inflammatory response that can negatively impact the differentiation capacity of adipogenic stem cells [17-19].

To begin to understand key mechanisms regulating adipose tissue deposition and expandability we utilized Adipose-derived Stem Cells (ASCs). These primary human cells are isolated from subcutaneous adipose tissue lipoaspirates, and are capable of differentiating into multiple lineages, including adipocytes, in vitro [20,21]. Because ASCs are derived directly from patient subcutaneous adipose depots, they provide a unique model system to investigate the control of adipocyte differentiation.

Neuregulin-1 (NRG1) is the first of four members of a signaling molecule family that serve as ligands for ErbB family receptors [22,23]. NRG1 plays important roles in regulating cell growth and differentiation of a variety of organs and tissues [22,23]. For example, it has been shown to be important in rodent cardiac development as knockout mice die at day E10.5 of heart failure [24] and also exhibit neurological defects [25]. Consistent with this, NRG1 has been implicated as a risk factor gene for schizophrenia and shown to play a variety of roles in neuronal function including cell migration, synapse formation, and myelination [23]. NRG1 has also been implicated in cancer [26,27]. Given these varied roles, it is unsurprising that NRG1 is a highly complex gene with alternative $5^{\prime}$ start sites and alternative splicing yielding at least 31 different isoforms and spanning over 1.4 million base pairs of genomic sequence on chromosome 8 [22,23].

We investigated a role for NRG1 in adipogenic differentiation because previous work has shown that it promotes neuronal stem-cell differentiation in the cerebral cortex [28] and retina [29] and also in vitro [30]. NRG1 also regulates differentiation of cardiac (heart) stem cells in vivo [31] and in vitro [32]. Because of this property NRG1 has shown promise in cardiac repair studies, often along with co-administered ASCs thought to play a role in paracrine signaling for regeneration [33-35]. However, no study has yet examined the role of NRG1 in adipose differentiation of ASCs. Furthermore, a previous study demonstrated that NRG1 is epigenetically regulated in breast cancer, where it may function as a tumor suppressor [36], prompting us to examine epigenetic regulation of this gene in ASCs.

In this study, we demonstrate a role for NRG1 as a regulator of adipose differentiation of ASCs, and that it is endogenously regulated by DNA methylation. Thus, Neuregulin-1 (NRG1) is a potential master regulator of WAT differentiation from subcutaneous primary human stem cells. We propose that epigenetic regulation of NRG1 establishes the adipose expandability limit for subcutaneous depots, providing a critical balance for metabolic health or disease.

\section{Materials and Methods}

\subsection{Stem Cell Culture}

Human Adipose-Derived Stem Cell (ASC) lines (Table 1) were cultured at $37^{\circ} \mathrm{C}$ with $5 \% \mathrm{CO}_{2}$ in Growth Media consisting of Dulbecco's Modified Eagle's Medium (DMEM) supplemented with $10 \%$ fetal bovine serum (FBS), $1 \%$ Penicillin $(10,000$ units $/ \mathrm{mL})$-Streptomycin $(10,000 \mu \mathrm{g} / \mathrm{mL})$, and $1 \mathrm{X}$ Glutamax. Growth Media was changed three times per week.

Table 1. Cell lines used in the study.

\begin{tabular}{|c|c|c|c|c|c|c|c|}
\hline Cell Line & BMI & Depot & Sex & Age & $\begin{array}{l}\text { Passage at } \\
\text { Experiment }\end{array}$ & Source & Figure \\
\hline $\begin{array}{l}\text { ASC080414A-derived } \\
\text { clonal line = AF2 }\end{array}$ & 25.1 & Abdomen & $\mathrm{F}$ & 39 & p12 & $\begin{array}{l}\text { Zen-Bio, Inc., Research } \\
\text { Triangle Park, NC, USA }\end{array}$ & $\begin{array}{c}\text { Figure } 1 \mathrm{~A}, \\
\text { Figure } 2 \mathrm{~B}, \\
\text { Figure } 3 \text { and } \\
\text { Figure } 4 \mathrm{~A}\end{array}$ \\
\hline ASC072709 & 38.0 & Hip & $\mathrm{F}$ & 39 & p9 & $\begin{array}{l}\text { Zen-Bio, Inc., Research } \\
\text { Triangle Park, NC, USA }\end{array}$ & Figure 4B \\
\hline Line 1107 & 27.4 & Abdomen & $\mathrm{F}$ & 40 & $\mathrm{p} 8$ & DeCicco-Skinner lab (AU) & Figure $4 \mathrm{C}$ \\
\hline ASC012502 & 25.3 & Abdomen & M & 40 & $\mathrm{p} 4$ & $\begin{array}{l}\text { Zen-Bio, Inc., Research } \\
\text { Triangle Park, NC, USA }\end{array}$ & Figure $2 \mathrm{C}$ \\
\hline
\end{tabular}


A

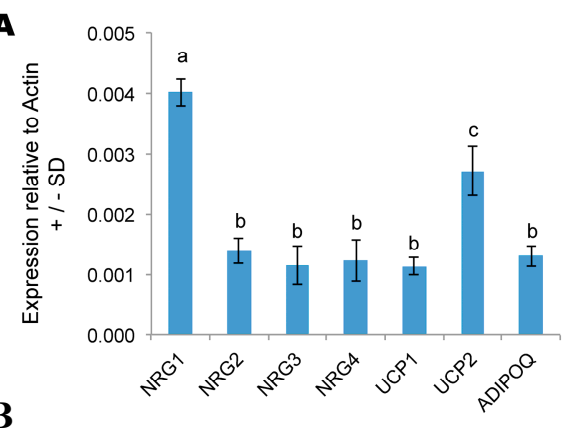

B

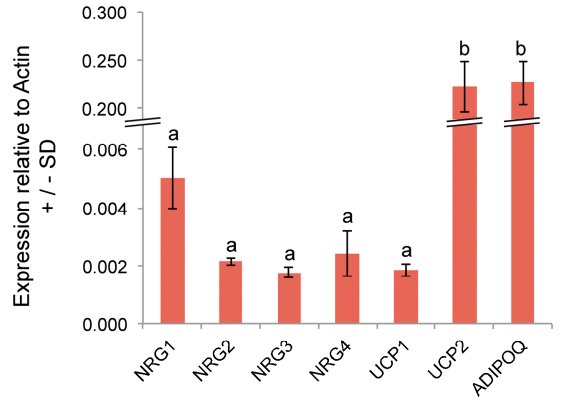

C
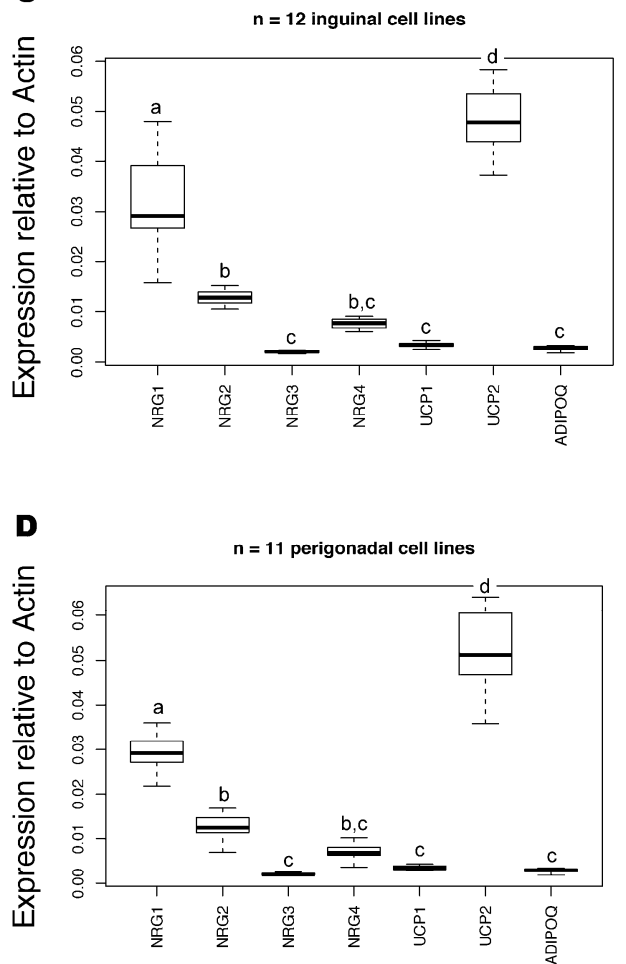

Figure 1. Expression of NRG1-4 and markers of brown (BAT) or white adipose tissue (WAT) in human and murine primary stem cells. (A) Data from human primary AF2 stem cells (ASCs). Statistical significance measured by 1-way ANOVA and Tukey's HSD post-hoc test. One-way ANOVA test statistics follow. For gene: $\mathrm{df}=6, \mathrm{SS}=2.198 \times 10^{-5}, \mathrm{MS}=3.664 \times 10^{-6}$; for residuals, $\mathrm{df}=14, \mathrm{SS}=1.049$ $\times 10^{-6}, \mathrm{MS}=7.500 \times 10^{-8} . \mathrm{F}=48.89$ and $\operatorname{Pr}(>\mathrm{F})<1.35 \times 10^{-8}$. By Tukey's HSD post-hoc test, NRG1 is significantly different $(p<0.001)$ from all other genes. Statistical groups are indicated by lowercase letters $(\mathrm{a}, \mathrm{b}, \mathrm{c})$, and all differ at the $p<0.001$ level. (B) Data from human primary adipose-differentiated AF2 cells. Statistical significance measured by 1-way ANOVA and Tukey's HSD post-hoc test. One-way ANOVA test statistics follow. For gene: $\mathrm{df}=6, \mathrm{SS}=0.2107, \mathrm{MS}=0.03512$; for residuals, $\mathrm{df}=14, \mathrm{SS}=0.0024$. 
MS $=0.00017 . \quad F=205$ and $\operatorname{Pr}(>F)<8.08 \times 10^{-13}$. By Tukey's HSD post-hoc test, only UCP2 and ADIPOQ are significantly different $(p<0.001)$ from all other genes. Statistical groups are indicated by lowercase letters ( $\mathrm{a}$ and $\mathrm{b}$ ), and differ at the $p<0.001$ level. (C) Analysis of gene expression in mouse adipose precursor cell lines isolated from inguinal depots of a male mouse. One-way ANOVA test statistics follow. For gene: $\mathrm{df}=6, \mathrm{SS}=0.022323, \mathrm{MS}=0.003720$; for residuals, $\mathrm{df}=77, \mathrm{SS}=0.002212$, MS $=0.000029 . \mathrm{F}=129.5$ and $\operatorname{Pr}(>\mathrm{F})<2 \times 10^{-16}$. By Tukey's HSD post-hoc test, NRG1 is significantly different $(p<0.001)$ from all other genes; statistical groups are indicated by lowercase letters $(\mathrm{a}-\mathrm{d})$, at the $p<0.05$ level. Indicated by " $\mathrm{n}$ " is the number of independent cell lines (biological replicates) isolated from immortomouse in [43], the source of expression data. (D) Gene expression in mouse adipose precursor cell lines isolated from perigonadal depots of a male mouse. One-way ANOVA test statistics follow. For gene: $\mathrm{df}=6, \mathrm{SS}=0.025450, \mathrm{MS}=0.004242$; for residuals, $\mathrm{df}=70, \mathrm{SS}=0.003065$, MS $=0.000044 . \mathrm{F}=96.87$ and $\operatorname{Pr}(>\mathrm{F})<2 \times 10^{-16}$. By Tukey's HSD post-hoc test, NRG1 is significantly different $(p<0.001)$ from all other genes; statistical groups are indicated by lowercase letters (a-d), at the $p<0.05$ level. Indicated by " $\mathrm{n}$ " is the number of independent cell lines (biological replicates) isolated from immortomouse in [43], the source of expression data. Abbreviations: NRG, Neuregulin; UCP, uncoupling protein; ADIPOQ, adiponectin. SS, Sum of Squares, MS, Mean Squares, dF, degrees of freedom, F, F-ratio. ASC, Adipose-derived Stem Cell.
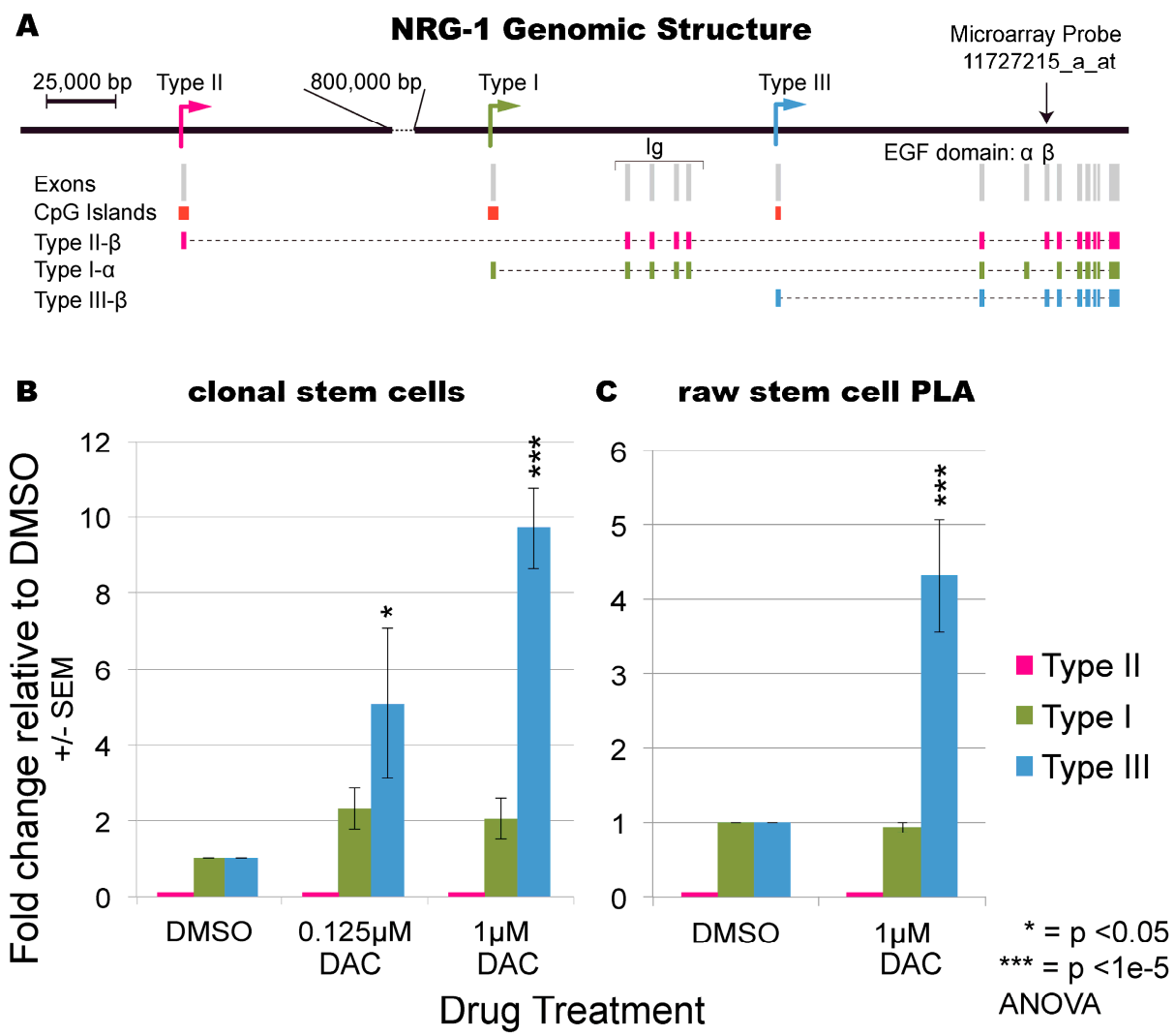

Figure 2. Isoform-specific epigenetic induction of NRG1 expression in primary human ASCs. (A) Genomic structure of NRG-1. Types I-III are alternative transcription start sites within the NRG1 locus, each carrying a unique first exon targeted in RT-qPCR. Induction specifically of Type III isoform was observed (B) in clonal AF2 cells and (C) raw processed lipoaspirate (PLA). P-values derived from Tukey's HSD post-hoc test after ANOVA and are relative to corresponding matched DMSO control. Each experiment was performed in triplicate and the fold-change and standard error of the mean are shown. 


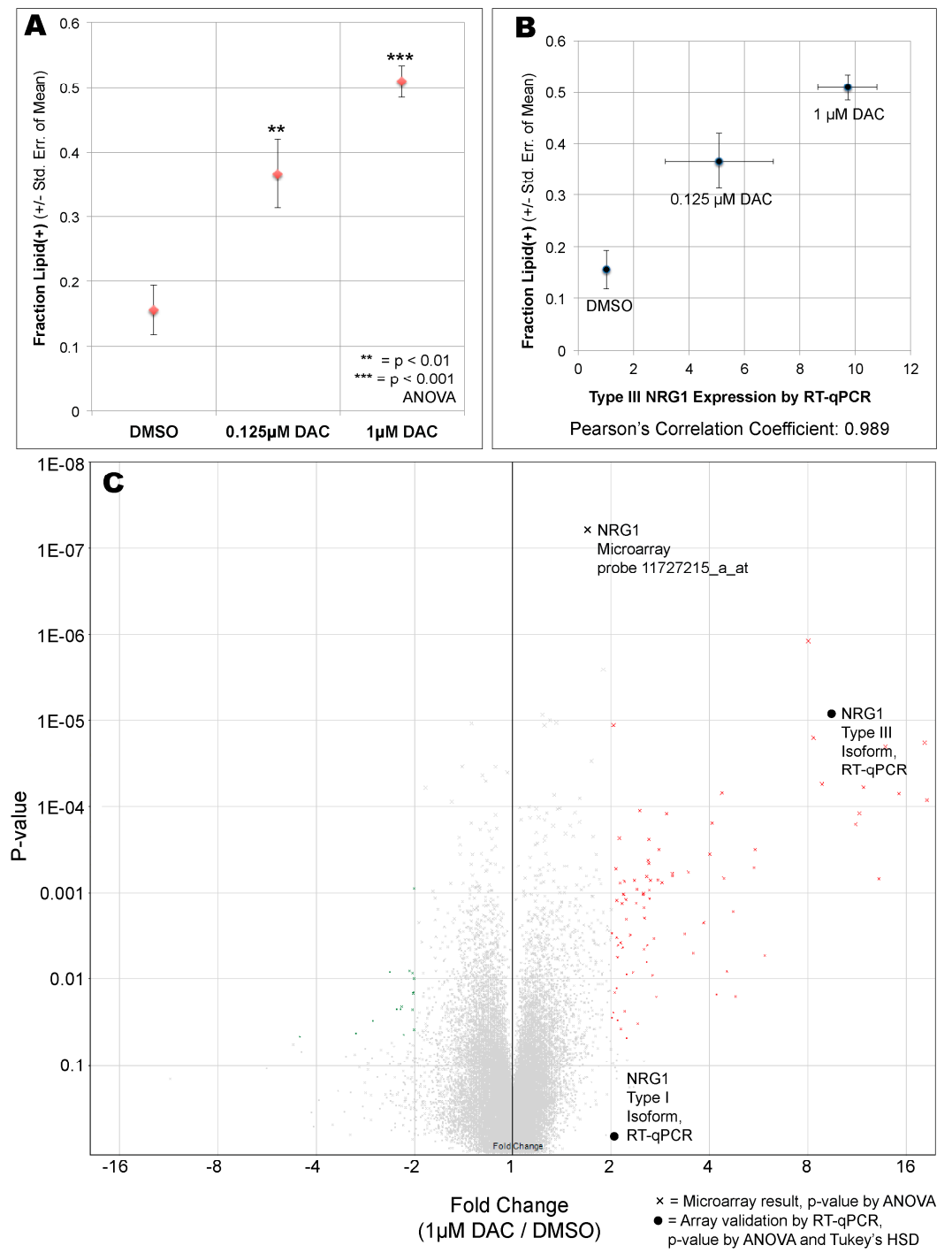

Figure 3. Epigenetic regulation in primary adipose-derived stem cells alters differentiation behavior. (A) Quantitation showing DAC causes increased differentiation. All experiments performed as three biological replicates, with error bars showing S.E.M. (B) The NRG1 microarray probe (11727215_a_at) correlates with differentiation: Pearson's correlation coefficient 0.989. (C) Volcano plot of microarray data, $1.0 \mu \mathrm{M}$ DAC vs. DMSO ( $P$-values by ANOVA). Validation by RT-qPCR is also shown on the volcano plot as filled circles at appropriate fold-change ( $p$-value calculated by ANOVA followed by Tukey's HSD post-hoc test).

\subsection{Generation of Clonal ASC Line}

Polyclonal ASC culture ASC080414A (Zen-Bio, Inc., Research Triangle Park, NC, USA) was trypsinized and neutralized in DMEM supplemented with 20\% FBS, 1\% Penicillin-Streptomycin, and $1 \mathrm{X}$ Glutamax, and quantified using a hemocytometer. Cells in suspension were then subjected to serial limiting dilution into a $96-$-well dish. After $12-24 \mathrm{~h}$, wells containing a single cell were identified by inspection and cultured to give rise to monoclonal ASC lines. After 1 week, monoclonal lines were switched back to standard growth media (DMEM with 10\% FBS, 1\% Penicillin-Streptomycin, 1X Glutamax). Clone F2 demonstrated strong growth, was renamed AF2 (short for ASC080414A-F2) and was used in epigenetic and differentiation experiments for gene expression analysis. 

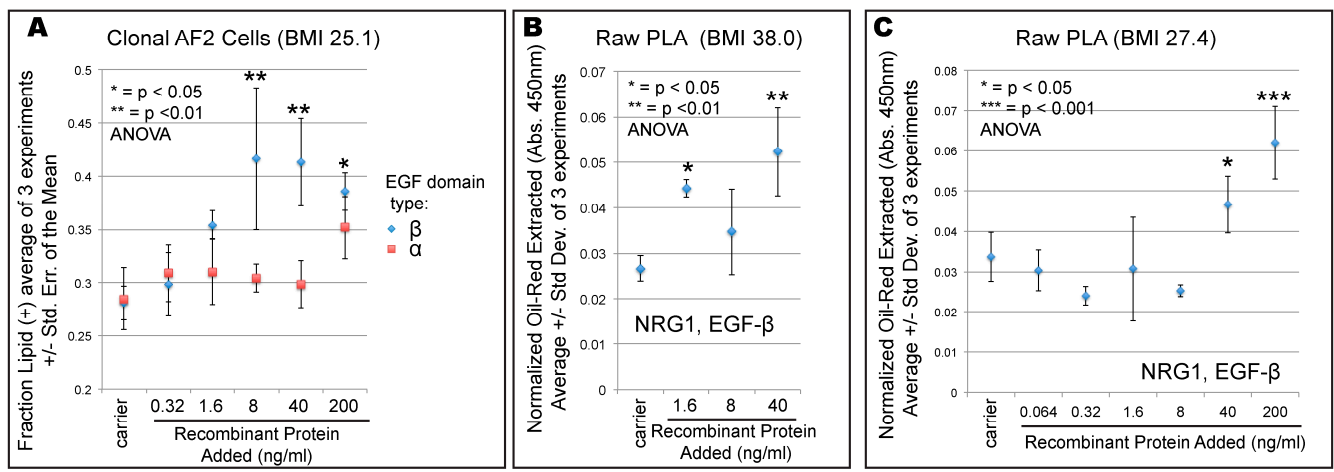

Figure 4. Recombinant NRG1 can re-program stem cells to greater differentiation. (A) Recombinant NRG1 encompassing either an EGF- $\alpha$ or EGF- $\beta$ domain was added to the culture media for AF2 clonal cells and adipose differentiation was measured. Shown is the average and standard error of the mean for 3 independent experiments, each with 3 replicates. (B) Validation with recombinant NRG1 EGF- $\beta$ in raw PLA (donor BMI = 38.0). Plotted is the average, with error bars representing $+/-$ one standard deviation of 3 biological replicates. The asterisks represent $p$-values of 1-way ANOVA relative to the carrier control. (C) Validation of recombinant NRG1 EGF- $\beta$ in raw PLA (donor BMI = 27.4). Plotted is the average, with error bars representing $+/-$ one standard deviation of 3 biological replicates. The asterisks represent $p$-values of 1-way ANOVA relative to the carrier control.

\subsection{Decitabine (DAC) Treatment and Adipose Differentiation}

AF2 cells (passage 8 ) were cultured to approximately $80 \%$ confluence in 6-well dishes (3 wells per treatment). 5-aza-2'-deoxycytidine (Decitabine, DAC) was diluted in DMSO to stock concentrations of $5 \mathrm{mM}$ and $0.625 \mathrm{mM}$. A total of $0.4 \mu \mathrm{L}$ of each stock solution of DAC was added to respective wells containing cells in $2 \mathrm{~mL}$ of Growth Media, giving final concentrations of $1 \mu \mathrm{M}$ and $0.125 \mu \mathrm{M}$. $0.4 \mu \mathrm{L}$ DMSO was added to 3 wells as carrier controls. DAC or DMSO was added once per day for 3 days, with no media change. On the fourth day, one set of replicates (total of 3 replicates per treatment) was harvested for DNA and RNA using ZR-Duet DNA/RNA MiniPrep (Plus) kit (Zymo Research, Irvine, CA, USA, Cat \# D7003) following manufacturer's protocol. Following extraction, RNA samples were further cleaned and concentrated using the RNA Clean \& Concentrator kit (Zymo Research Cat \# R1013) into $15 \mu \mathrm{L}$ of DNAse/RNase-Free Water as per the manufacturer's protocol. RNA was sent to the Deep Sequencing Core at Johns Hopkins for Affymetrix Microarray analysis.

Additional DAC or DMSO-treated AF2 replicates (three per treatment) were switched to Adipogenic Media and cultured for 18 days, at which point adipocyte differentiation was quantitated by imaging. The adipogenic differentiation media consisted of DMEM supplemented with 10\% FBS, 1\% Penicillin Streptomycin, 1X Glutamax, 1.0 $\mu \mathrm{M}$ Dexamethasone, $0.5 \mathrm{mM}$ IBMX (3-isobutyl-1-methylxanthine), $0.2 \mathrm{mM}$ Indomethacin, and $10.0 \mu \mathrm{M}$ Insulin.

\subsection{NRG1 Recombinant Protein Experiment in 6-Well Dishes}

Two recombinant NRG1 isoforms, NRG1- $\alpha$, Cat \#559502 and NRG1- $\beta$, Cat \#711104 were ordered from BioLegend (San Diego, CA, USA). NRG1- $\alpha$ (65 amino acids) was diluted in DPBS supplemented with $1 \%$ Bovine Serum Albumin (BSA) to $40 \mathrm{ng} / \mu \mathrm{L}, 8 \mathrm{ng} / \mu \mathrm{L}, 1.6 \mathrm{ng} / \mu \mathrm{L}, 0.32 \mathrm{ng} / \mu \mathrm{L}$, and $0.064 \mathrm{ng} / \mu \mathrm{L}$. NRG1- $\beta$ (65 amino acids) was reconstituted in to $200 \mathrm{ng} / \mu \mathrm{L}$ in sterile $\mathrm{H}_{2} \mathrm{O}$ supplemented with $5 \%$ Trehalose as recommended by the manufacturer, and serially diluted to the same concentrations as NRG1- $\alpha$. These stocks provided 1:1000 dilutions, and $2 \mu \mathrm{L}$ of each was added to corresponding wells of a 6-well dish (approximately $80 \%$ confluence) along with fresh growth media. For controls, $2 \mu \mathrm{L}$ of $1 \%$ BSA or $5 \%$ Trehalose were used and 3 wells were left untreated. Stem cells were allowed to grow for 3 days with recombinant NRG1 (or carrier control) to reach 100\% confluence and then were switched to adipogenic media (DMEM with 10\% FBS, 1\% Penicillin Streptomycin, 1X Glutamax, $1.0 \mu \mathrm{M}$ Dexamethasone, 0.5 mM IBMX (3-isobutyl-1-methylxanthine), $0.2 \mathrm{mM}$ Indomethacin, and $10.0 \mu \mathrm{M}$ 
Insulin) and allowed to differentiate for 18 days (without recombinant protein). On day 18, differentiation was quantified by microscopic imaging. For each well, 4 "light" images (showing all the cells present in the field of view) and 4 corresponding "dark" images (using high contrast to highlight lipid droplets characteristic of adipocytes) were taken. The total number of cells, as well as the number of lipid (+) adipocytes, present in an image was determined using ImageJ software.

\subsection{Adipocyte Differentiation Quantitation with Oil Red O in 24-Well Dishes}

NRG1 validation experiments were conducted in 24-well dishes, cultured and treated with the same concentrations of recombinant protein as described for the 6-well dish experiment. As in the 6-well dish experiments, differentiation occurred for 18 days after the switch to adipogenic media.

The differentiation was quantitated with Oil Red O (OrO). Oil Red O (OrO) working solution was prepared: OrO stock solution (generated by mixing $0.3 \mathrm{~g}$ Oil Red O powder, Santa Cruz Biotech, Dallas, TX, USA, CAS\# 1320-06-5) was dissolved into $100 \mathrm{~mL}$ of $100 \%$ isopropanol. From this stock, a working solution was created by adding $24 \mathrm{~mL}$ OrO stock to $16 \mathrm{~mL}$ distilled $\mathrm{H}_{2} \mathrm{O}\left(\mathrm{dH}_{2} \mathrm{O}\right)$, which was mixed thoroughly and allowed to stand for $10 \mathrm{~min}$ prior to filtration through a $0.2 \mu \mathrm{M}$ vacuum filter unit (VWR, Philadelphia, PA, USA, Cat \# 10040-460) to remove particulates. This working stock is usable for up to $3 \mathrm{~h}$.

For all experiments, several wells of an unseeded 24-well dish were used as no-cell controls, because of a marked tendency for OrO to stick to polystyrene. All differentiated stem cells and the no-cell control wells were washed with DPBS ( $1 \mathrm{~mL}$ per well, Gibco, Gaithersburg, MD, USA, Cat\# 14190144) and fixed for $30 \mathrm{~min}$ with $1 \mathrm{~mL}$ of PBS (pH 7.2) supplemented with $4 \%$ paraformaldehyde and $1 \% \mathrm{CaCl}_{2}$. After fixing, cells were washed once with DPBS and stained with $1 \mathrm{~mL}$ of OrO working solution for $15 \mathrm{~min}$. OrO working solution was removed and the wells were washed with $\mathrm{dH}_{2} \mathrm{O}$ three times. To prevent drying out, one dish was aspirated and re-filled at a time; if wells dry out lipid and the OrO signal within the cells is lost. After final wash and aspirate, the OrO signal was eluted by adding $1 \mathrm{~mL}$ of $100 \%$ isopropanol to all wells and gently rocking for $15 \mathrm{~min}$ (visually confirm elution under the microscope and allow more time if required). After extraction, pipet $100 \mu \mathrm{L}$ of the isopropanol-OrO into a clean 96-well plate; measure each extracted sample in triplicate (three wells in the 96 well plate) as technical replicates. To quantify OrO extraction, measure absorbance at $450 \mathrm{~nm}$ with a microplate reader; perform subtraction of average no-cell control signal to correct for background binding to polystyrene.

\subsection{NRG1 Isoform Expression Analysis}

RNA was extracted and DNAseI-treated from DAC-treated AF2 cells using the ZR-Duet DNA/RNA MiniPrep (Plus) kit (Zymo Research Cat \# D7003). This RNA was converted to cDNA using SuperScript III First-Strand Synthesis System (Invitrogen, Carlsbad, CA, USA, Cat\# 18080051) according to manufacturer's instructions. Quantitative PCR was carried out using PowerSYBR master mix (ThermoFisher Cat\# 4367659) utilizing primers specific to the unique first exon of each NRG1 isoform (Type I, Type II, and Type III, STAR methods). Beta-Actin primers obtained from Huang et al. [37] were used as a normalization control. The qPCR used a 2-step program, with 40 cycle of $95^{\circ} \mathrm{C}$ denature (30s) and $60^{\circ} \mathrm{C}$ anneal/extend (60s).

\subsection{Microarray Analysis and Volcano Plot}

DAC and DMSO-treated control RNA was evaluated using an Affymetrix PrimeView Human Gene Expression Array run at the Johns Hopkins Deep Sequencing and Microarray Core Facility. The data was evaluated on the Transcriptome Analysis Console (ThermoFisher) v. 3.1.0.5 using the one-way ANOVA and volcano plot function. 


\subsection{Bisulfite Conversion and PCR}

DNA was isolated from DAC-treated 414A F2 monoclonal cell line, and $250 \mathrm{ng}$ of DNA was bisulfite converted per sample using the EZ DNA Methylation-Gold kit (Zymo Research) according to the manufacturer's protocol. PCR was performed on bisulfite-converted material with "Bisulfite CpG Island III" primers using the following program: (step 1) $94{ }^{\circ} \mathrm{C} 2 \mathrm{~min}$, (step 2) $94{ }^{\circ} \mathrm{C} 30 \mathrm{~s}$, (step 3) $49^{\circ} \mathrm{C} 30 \mathrm{~s}$, (step 4$) 72{ }^{\circ} \mathrm{C}$ for $30 \mathrm{~s}$, repeat steps $2-4$ for 40 cycles, (step 5) $72{ }^{\circ} \mathrm{C}$ for $5 \mathrm{~min}$, (step 6) $4{ }^{\circ} \mathrm{C}$ infinite hold.

\section{Results}

Given that NRG4 is a marker for brown adipose tissue (BAT) [38], we investigated the expression of all four Neuregulin paralogs (NRG1-4) in primary clonal human white adipose-derived stem cells (ASCs) and in vitro differentiated adipocytes. While the stem cells (AF2) express only negligible levels of NRG 2-4, they exhibit detectable levels of NRG1 (Figure 1A). When we differentiate these cells into adipocytes, UCP2 and adiponectin expression are strongly induced (Figure 1B) along with leptin and perilipin-1 as shown in our previous study [39]. Because UCP2 is expressed within WAT and other tissues, but not BAT [40,41], which instead preferentially expresses UCP1 [42], we conclude that AF2 cells show an expression profile consistent with WAT. Furthermore, the expression pattern in murine cell lines resembles the human ASC pattern (Figure 1A,C,D). This is true both for inguinal (subcutaneous, Figure 1C) and perigonadal (visceral, Figure 1D) fat pads (data from [43]).

Because of NRG1's well established role promoting differentiation of stem cells in neuronal [28], retinal [29] and heart [31] tissue, we hypothesized that NRG1 may be critical in defining the differentiation potential of WAT stem cells. Given that previous work has shown that breast cancer cells use DNA methylation to inhibit NRG1 [36] we investigated the potential for epigenetic regulation in AF2 cells. We exposed AF2 cells to the DNA methylation inhibitor 5-aza-2'-deoxycytidine (DAC) and assessed expression of three NRG1 isoforms, each with a unique transcriptional start site leading to expression of a unique $5^{\prime}$ exon (Figure 2A, [22]) by RT-qPCR analysis. To ensure accurate normalization we measured the expression of four different housekeeping genes in stem cells and adipocytes from microarray data on adipogenic differentiation of AF2 cells from our previous study [39] (Figure S1). Our data show that $\beta$ actin is uniformly expressed across differentiation and thus very suitable as a normalization control (Figure S1).

While NRG1 Type I isoform was mildly induced ( 2-fold) by DAC treatment and the Type II isoform was not detected, the Type III isoform exhibited a five-fold and ten-fold up-regulation upon treatment with $0.125 \mu \mathrm{m}$ and $1 \mu \mathrm{m}$ DAC respectively (Figure 2B). The same pattern was observed on DAC treatment of raw PLA (Figure 2C) showing that epigenetic regulation of NRG1 Type III isoform may be a general mechanism.

The increased NRG1 Type III expression induced by DAC treatment correlated with increased cellular differentiation 18 days later in the same experiment (Figure 3A). Remarkably, the Pearson's correlation between adipose differentiation and Type III isoform expression after DAC treatment was 0.989 (Figure 3B). To test whether other genes might be driving this effect, we performed microarray analysis on the DAC-treated AF2 stem-cell RNA. A probe within NRG1 (11727215_a_at, Figure 2A) showed by far the most statistically robust change between DMSO and $1 \mu \mathrm{M} \mathrm{DAC} \mathrm{(Figure} 3 \mathrm{C}$ ), though it was not the highest fold-change. This probe is in a universal exon so it reports all isoforms together (Figure 2A); by plotting the RT-qPCR data onto the volcano plot this probe may have predominantly reported the Type I isoform's 2-fold increase (Figure 2B). In contrast, the NRG1 Type III isoform expression increased approximately ten-fold by RT-qPCR (Figures 2B and $3 \mathrm{C}$ ).

In contrast to NRG1, no other DAC-upregulated genes were compelling candidate regulators of cellular differentiation (Figure 3C, Table 2 and Table S1). However, the top two significantly upregulated genes by fold-change, Keratin-8 (KRT8) [44] and Metallothionein 1G (MT1G) [45] (Table 2), are known to be epigenetically regulated, specifically through DNA methylation of their promoters, in cancer cell lines. Thus, the strongly DAC-upregulated genes from the microarray analysis (Table 2) appear to 
represent 'endogenous epigenetic reporters' whose expression shows how well DAC treatment worked in cell culture. The strong DAC-responsiveness of NRG1 type III isoform expression (Figure 2B,C) prompted bisulfite-PCR examination of its associated CpG island (Figure 2A) which is only 240 bp long and encodes 16 CpG motifs, making it suitable for bisulfite PCR analysis. Using DNA isolated from the same stem cells experiment as Figure 3, we show that while partial methylation $(\sim 50 \%$ at most CpG sites) could be seen in the DMSO control, it was not decreased upon treatment with $1 \mu \mathrm{m}$ DAC, and if anything the methylation increased (Figure S2). While this is not unprecedented-DAC has been shown to increase methylation in some genomic locations [46] - it suggests that the epigenetic control point in the genome is unknown. We also cannot rule out the possibility that another epigenetically-regulated transcription factor in turn controls NRG1 type III expression; however, from the microarray expression data, none of the most up-regulated genes after DAC treatment were transcription factors (Table 2), so this explanation appears less likely.

To test whether NRG1 EGF domain is a driver of increased adipose differentiation, we tested the effect of recombinant NRG1 EGF domains on cultured cells. To mirror the DAC experiment we only exposed stem cells to recombinant protein for 3 days prior to induction of differentiation with adipogenic media (see Section 2.4.). Subsequent differentiation was performed with non-supplemented adipogenic media-in other words, the cells were only exposed to recombinant protein for their last 3 days as stem cells. The recombinant NRG1 peptides tested encompassed only 65 amino acids of the EGF domain, and we tested both $\alpha$ and $\beta$ isoforms (Figure $4 \mathrm{~A}$ ). After 18 days of adipogenic differentiation we observed a statistically significant near-doubling of adipose differentiation specifically in the NRG1- $\beta$ treated culture, recapitulating the effect of DAC (Figure 4A). This effect was replicated in two different 'raw' PLA culture of obese (BMI 38, Figure 4B) and overweight (BMI 27.4, Figure 4C) patients to verify the effect is general to more than one cell line or one patient, and does not require clonal lines to be observed. We also note that the DAC-upregulated microarray probe is in the NRG1- $\beta$ exon (Figure 2A) consistent with the active isoform in our experiment (Figure 4A).

Table 2. All genes at least 4-fold upregulated on $1 \mu \mathrm{M}$ DAC relative to DMSO control. $p$-values from ANOVA for microarray probe. RT-qPCR validation for NRG1 Type III shown in bold ( $p$-value from Student's 2-tailed $t$-test).

\begin{tabular}{|c|c|c|c|c|}
\hline Transcript Cluster ID & $\begin{array}{l}\text { Fold Change (1 uM } \\
\text { DAC vs. DMSO) }\end{array}$ & $\begin{array}{c}\text { ANOVA } p \text {-Value (1 } \\
\text { uM DAC vs. DMSO) }\end{array}$ & Gene Symbol & Description \\
\hline 11752634_x_at & 18.58 & 0.000084 & KRT8 & keratin 8 , type II \\
\hline 11758298_x_at & 18.25 & 0.000018 & KRT8 & keratin 8, type II \\
\hline 11756989_x_at & 15.22 & 0.000071 & KRT8 & keratin 8 , type II \\
\hline 11758184_x_at & 13.85 & 0.00002 & KRT8 & keratin 8, type II \\
\hline 11717386_s_at & 13.22 & 0.000681 & MT1G & metallothionein $1 \mathrm{G}$ \\
\hline 11758188_x_at & 11.85 & 0.00006 & KRT8 & keratin 8, type II \\
\hline 11758301_x_at & 11.51 & 0.000118 & KRT8 & keratin 8 , type II \\
\hline 11758183_x_at & 11.23 & 0.000159 & KRT8 & keratin 8, type II \\
\hline RT-qPCR_NRG1_Type III & 9.72 & 0.0000098 & NRG1 & Neuregulin-1 \\
\hline 11727248_a_at & 8.85 & 0.000055 & MYH3 & myosin, heavy chain 3 \\
\hline 11733121_s_at & 8.33 & 0.000016 & DAZL & $\begin{array}{c}\text { deleted in } \\
\text { azoospermia-like }\end{array}$ \\
\hline 11715280_s_at & 8.03 & 0.000001 & KRT17 & keratin 17 , type I \\
\hline 11756072_s_at & 5.92 & 0.005264 & SAA1 & serum amyloid A1 \\
\hline 11727092_x_at & 5.53 & 0.000309 & IL18 & interleukin 18 \\
\hline 11730408_a_at & 5.48 & 0.00051 & C19orf33 & $\begin{array}{l}\text { chromosome } 19 \text { open } \\
\text { reading frame } 33\end{array}$ \\
\hline 11753131_x_at & 4.81 & 0.015946 & TM4SF1 & $\begin{array}{l}\text { transmembrane } 4 \mathrm{~L} \\
\text { six family member } 1\end{array}$ \\
\hline 11717387_x_at & 4.73 & 0.00164 & MT1G & metallothionein $1 \mathrm{G}$ \\
\hline 11753130_at & 4.52 & 0.008248 & TM4SF1 & $\begin{array}{l}\text { transmembrane } 4 \mathrm{~L} \\
\text { six family member } 1\end{array}$ \\
\hline 11755287_x_at & 4.43 & 0.000674 & KRT8 & keratin 8 , type II \\
\hline 11756334_x_at & 4.37 & 0.00007 & ANXA3 & annexin A3 \\
\hline 11753129_a_at & 4.21 & 0.015138 & TM4SF1 & $\begin{array}{l}\text { transmembrane } 4 \mathrm{~L} \\
\text { six family member } 1\end{array}$ \\
\hline 11724283_a_at & 4.08 & 0.000154 & ANXA3 & annexin $\mathrm{A} 3$ \\
\hline 11718347_a_at & 4.01 & 0.000348 & S100P & $\begin{array}{l}\text { S100 calcium binding } \\
\text { protein } \mathrm{P}\end{array}$ \\
\hline
\end{tabular}




\section{Discussion}

Neuregulin-4 (NRG4) is a brown adipose marker, identified by transcriptomic analysis of 'browned' fat, and may function as an adipokine signal from BAT to neurons [38]. While we find NRG4 is expressed at negligible levels in in vitro primary human WAT stem cell culture, we find NRG1 is more highly expressed, both in human (Figure 1A) and mouse (Figure 1B,C). Furthermore, NRG1 is epigenetically inducible in human WAT stem cells (Figure 2B,C), suggesting it is the WAT-specific neuregulin, a natural counterpart to BAT-specific NRG4. Our analysis of epigenetically inducible NRG1 isoforms showed that a membrane-bound isoform (Type III) is most strongly inducible, suggesting that its role may be more autocrine/juxtacrine than endocrine, potentially acting locally to modulate stem cell differentiation levels within the tissue itself. Because ASCs are primary human cells and tested within 4-12 passages of isolation (Table 1), they retain the patient-encoded epigenetic information and provide a remarkable model system to study adipose-relevant biology. Through a series of experiments, we demonstrate epigenetic regulation of NRG1 by DNA methylation regulates the differentiation of WAT stem cells in vitro.

This role is consistent with the documented function of NRG1 in other tissues. As already mentioned briefly, in neurons, NRG1 promotes neuronal cell differentiation in the cerebral cortex [28] and retina [29], both in vivo, and promotes neuronal differentiation in vitro [30]. Similarly, in the heart, NRG1 promotes differentiation of cardiomyocytes from their stem cell progenitors both in vivo [31] and in vitro [32] and for this reason NRG1 has been successfully tested in clinical trials for heart failure $[47,48]$. Our results are the first to identify the same differentiation-promoting function of NRG1 within primary adipose-derived stem cell culture.

We hypothesize that the epigenetic control of NRG1 may constitute an intrinsic mechanism-a molecular rheostat-limiting the expansion of subcutaneous WAT depots. In turn, the limits of adipose expansion lead to negative metabolic consequences via ectopic lipid deposition in muscle, liver, or visceral adipose depots [11,12]. Here, we suggest that this limiting mechanism is in fact a stem-cell intrinsic epigenetic mechanism acting through NRG1 as a master regulator.

The identification of NRG1 as a key regulator of adipose expansion may provide a novel therapy for obesity. Wild-type mice treated with injections of recombinant NRG1 display metabolic benefits including lowered bodyweight and reduction in percent body fat relative to controls [49]. NRG1 also improved cardiovascular function and attenuated nephropathy in an apoE mutant mouse model [50]. In an obese mouse model (the $d b / d b$ leptin receptor mutant), NRG1 injections improved glucose tolerance [51]. Therefore NRG1 is a candidate for treating metabolic syndrome. When NRG1 was used in clinical trials for human heart failure $[47,48]$ no effect on bodyweight was noted; however, the human therapies were brief, 10-11 days, whereas the mouse studies took 8 weeks. Despite multiple studies of systemic administration of recombinant NRG1 in rodents, all of which demonstrated positive metabolic effects [49-53], no study has examined its role in adipose expansion directly. This is even more surprising given that NRG1 administration in mice caused a dramatic spike in leptin, an adipocyte-secreted hormone [49]. Elevated levels of leptin in mouse models promotes reductions in body weight through its effects on the leptin receptor in critical brain regions that regulate food intake and energy expenditure [54].

The dosages of recombinant NRG1 that were active in our experiments are physiologically relevant. Human blood contains variable levels of circulating NRG1 EGF- $\beta$ isoform, regulated by physical fitness, from 2.6 to $473 \mathrm{ng} / \mathrm{mL}[55,56]$, and within the range of our observed in vitro activity (Figure $4 \mathrm{~A}-\mathrm{C}$ ). Even correcting for the size differences between the tested 65aa recombinant fragment and full-length NRG1 $(40 \mathrm{kDa},[56])$ the active concentrations we uncovered are within the physiological range. We also note that the Type III isoform is predicted to remain anchored to the membrane [22] where its effective concentration may be very high for cells in contact with each other in a juxtacrine/autocrine mechanism.

Our data reveal 3-day incubation of recombinant NRG1 $\beta$-EGF with ASC is sufficient to reprogram differentiation levels up to 18 days later, without continuous NRG1 exposure. While there is some 
endogenous bovine NRG1 in the serum used in the culture media, this was accounted for by measuring differentiation of carrier-only controls which were exposed to the same batch of cell culture media.

Our findings also have implications for experimental design. In this study we show that it is possible to treat cells with a non-specific epigenetic agent (decitabine) and to uncover a specific gene (NRG1) by incorporating phenotypic behavior (adipocyte differentiation) as an additional readout. Not only was the NRG1 probe upregulated, but its expression (in stem cells) always tracked very closely with differentiation behavior over two weeks later (Pearson's correlation 0.989, Figure 3B). This also highlights the value of using clonal cells, minimizing epigenetic noise and cellular heterogeneity of raw PLA [43], and quantitatively evaluating gene expression relative to behavior.

An important future question is to identify the receptor of the NRG1 ligand. Strong candidates are the ErbB family of proteins known to function as NRG1 receptors in other tissues including the brain [57,58]. Interestingly, ErbB gene 4 (ERBB4) has been identified in GWAS studies of both human obesity [59] and diabetic kidney disease [60,61]. These data add a genetic component to the epigenetics of NRG1 and highlight the importance of the NRG1-ErbB signaling axis in human obesity and metabolic health.

The genomic locus where DNA methylation regulates NRG1 expression remains undefined. We found that DNA methylation of the most obvious epigenetic regulatory site-the CpG island just upstream of the Type III promoter (Figure 2A) - is not decreased in the DAC-treated cells (Figure S2). Given the complexity of 3D genome architecture [62], DNA methylation can regulate expression of genes located at large genomic distances. Another possibility is that another gene is upregulated by the epigenetic mechanism directly, and acts as a transcription factor for the NRG1 Type III isoform, though our microarray analysis suggests this is not the case (Table 2). Either way, the epigenetic regulation appears to act at a distance (whether mediated by another gene or not) and the precise epigenetic control point remains to be discovered, a focus of future studies.

Our work is an important contribution to the epigenetic regulation of adipogenesis in vitro due to the use of primary human subcutaneous adipose-derived cells. Much previous work utilized 3T3-L1 cells, which are of an unknown lineage from mouse, not human, and are a transformed cell line, not primary cultures [63]. Nonetheless, epigenetic regulation of adipogenic differentiation has been documented in several 3T3-L1 studies [64,65].

Within the human ASC literature, one study demonstrated that inhibiting DNA methylation activates mir193b, thereby promoting adipogenesis of human ASCs [66] suggesting a non-coding RNA signaling axis that may synergize with NRG1-ErbB to promote differentiation. Another study showed that azacitidine treatment inhibits differentiation of ASCs [67], but in that study stem cells were isolated by bariatric and dermolipectomy surgery, not from subcutaneous lipoaspirate, raising the possibility that they represent a different depot (possibly visceral if obtained from bariatric patients). Visceral and subcutaneous depots behave differently and the interplay between visceral and subcutaneous depots may be metabolically critical $[15,68]$. Another study used bone-marrow derived mesenchymal stem cells (MSCs) to show decitabine (DAC) inhibits adipose differentiation, but these are different cells, from a different depot, than lipoaspirate-derived ASCs [69]. All these studies highlight the diversity of cellular responses to epigenetic modifying compounds, which is particularly important to keep in mind given that ASCs actually represent a heterogeneous mixture [43] and may contain individual cell types that respond differently to epigenetic modulator compounds. We hypothesize that some individual cell lineages within PLA may be 'positive responders' and some may be 'negative responders' but if they cross regulate each other the overall effect on differentiation may be quite complex and unpredictable or variable from PLA to PLA. This is particularly true as ratios of positive responders and negative responders may even be variant across time within the same culture. We therefore performed most of our work with a clonal line, AF2, which yielded clear results; we then confirmed the findings in raw PLA cultures. It is important to distinguish patient-to-patient variability from intra-patient heterogeneity; even passage numbers affect cellular behavior [70]. 
While circulating NRG1 has previously been shown to act directly on the central nervous system [28,71], liver [52,71], skeletal muscle [72], and cardiac muscle [31] here we propose an additional site of action within adipose tissues. We present a model that Type III NRG1 is epigenetically regulated and endogenously produced within adipose as a molecular rheostat controlling adipose expandability. In this model, the function of NRG1 is identical to previously published roles positively regulating stem-cell differentiation $[28,31]$. While this model was developed from in vitro data, it explains the dramatic rise in leptin (a primarily adipocyte-secreted hormone) upon administration of NRG1 to wild-type mice [49]; it also may help account for the positive metabolic effects of NRG1 administration to rats [52], hamsters [53] and an obese mouse model [51]. An important direction for future research is to test the model in a rodent by administering NRG1 protein and testing directly for increased adipose expandability, with the ultimate goal of developing therapies for human metabolic syndrome.

Supplementary Materials: The following are available online at http://www.mdpi.com/2073-4409/9/5/1148/s1, Figure S1: Analysis of housekeeping gene expression and adipose stem cell differentiation. Average expression was calculated as genometric mean of three biological replicates, Figure S2: Bisulfite PCR analysis of NRG1 Type III CpG island. Bisulfite treatment causes cytosine $(C$, blue) to sequence as thymidine ( $T$, green). Methylation is detected as retention of cytosine (blue traces) relative to $\mathrm{T}$ (green traces) on chromatograms (for clarity, G and A traces omitted). Note that $1 \mu \mathrm{m}$ DAC does not demethylate this locus. Arrows mark CpG sites where methylation can occur, Table S1: All genes significantly upregulated or downregulated by DAC in volcano plot.

Author Contributions: E.C.C. performed DAC treatment for microarray analysis, NRG1 isoform expression analysis by RT-qPCR, and NRG1 testing with recombinant peptide. R.S. and Y.A. performed stem cell culture experiments supporting the project. E.S.P. performed DAC treatment of stem cells. A.D.C. wrote the manuscript with J.R.B. who supervised all work on the project and designed the experiments. All authors have read and agreed to the published version of the manuscript.

Funding: This work was supported by two AU Faculty Research Support Grants, one to J.R.B. and another to both J.R.B. and DeCicco-Skinner. This work was also supported by NIH grant 1K22CA184297 to J.R.B.

Acknowledgments: The authors wish to thank Deborah Clegg for valuable comments on the manuscript. The authors also acknowledge Kathleen DeCicco-Skinner for sharing ASC line 1107 and for providing invaluable help in cell culture for ASCs. The authors also acknowledge Haiping Hao at the Johns Hopkins Deep Sequencing and Microarray Core Facility.

Conflicts of Interest: The authors declare no competing interests.

\section{References}

1. Hales, C.M.; Carroll, M.D.; Fryar, C.D.; Ogden, C.L. Prevalence of Obesity Among Adults and Youth: United States, 2015-2016. NCHS Data Brief 2017, 1-8. Available online: https://www.ncbi.nlm.nih.gov/pubmed/29155689.

2. Upadhyay, J.; Farr, O.; Perakakis, N.; Ghaly, W.; Mantzoros, C. Obesity as a Disease. Med. Clin. North Am. 2018, 102, 13-33. [CrossRef] [PubMed]

3. Gustafson, B.; Hedjazifar, S.; Gogg, S.; Hammarstedt, A.; Smith, U. Insulin resistance and impaired adipogenesis. Trends Endocrinol. Metab. 2015, 26, 193-200. [CrossRef] [PubMed]

4. Hayashi, T.; Boyko, E.J.; Leonetti, D.L.; McNeely, M.J.; Newell-Morris, L.; Kahn, S.E.; Fujimoto, W.Y. Visceral adiposity and the risk of impaired glucose tolerance: A prospective study among Japanese Americans. Diabetes Care 2003, 26, 650-655. [CrossRef] [PubMed]

5. Rosito, G.A.; Massaro, J.M.; Hoffmann, U.; Ruberg, F.L.; Mahabadi, A.A.; Vasan, R.S.; O'Donnell, C.J.; Fox, C.S. Pericardial fat, visceral abdominal fat, cardiovascular disease risk factors, and vascular calcification in a community-based sample: The Framingham Heart Study. Circulation 2008, 117, 605-613. [CrossRef]

6. Bluher, M. The distinction of metabolically "healthy" from "unhealthy" obese individuals. Curr. Opin. Lipidol. 2010, 21, 38-43. [CrossRef]

7. Goncalves, C.G.; Glade, M.J.; Meguid, M.M. Metabolically healthy obese individuals: Key protective factors. Nutrition 2016, 32, 14-20. [CrossRef]

8. Oh, Y.H.; Moon, J.H.; Kim, H.J.; Kong, M.H. Visceral-to-subcutaneous fat ratio as a predictor of the multiple metabolic risk factors for subjects with normal waist circumference in Korea. Diabetes Metab. Syndr. Obes. 2017, 10, 505-511. [CrossRef]

9. Shafqat, M.N.; Haider, M. Subcutaneous to visceral fat ratio: A possible risk factor for metabolic syndrome and cardiovascular diseases. Diabetes Metab. Syndr. Obes. 2018, 11, 129-130. [CrossRef] 
10. Hwang, Y.-C.; Hayashi, T.; Fujimoto, W.Y.; Kahn, S.E.; Leonetti, D.L.; McNeely, M.J.; Boyko, E.J. Visceral abdominal fat accumulation predicts the conversion of metabolically healthy obese subjects to an unhealthy phenotype. Int. J. Obes. 2015, 39, 1365-1370. [CrossRef]

11. Virtue, S.; Vidal-Puig, A. It's not how fat you are, it's what you do with it that counts. PLoS Biol. 2008, 6, e237. [CrossRef] [PubMed]

12. Virtue, S.; Vidal-Puig, A. Adipose tissue expandability, lipotoxicity and the Metabolic Syndrome-an allostatic perspective. Biochim. Biophys. Acta 2010, 1801, 338-349. [CrossRef] [PubMed]

13. Gustafson, B.; Smith, U. Regulation of white adipogenesis and its relation to ectopic fat accumulation and cardiovascular risk. Atherosclerosis 2015, 241, 27-35. [CrossRef] [PubMed]

14. Neeland, I.J.; Ross, R.; Després, J.-P.; Matsuzawa, Y.; Yamashita, S.; Shai, I.; Seidell, J.; Magni, P.; Santos, R.D.; Arsenault, B.; et al. Visceral and ectopic fat, atherosclerosis, and cardiometabolic disease: A position statement. Lancet Diabetes Endocrinol. 2019, 7, 715-725. [CrossRef]

15. Lessard, J.; Laforest, S.; Pelletier, M.; Leboeuf, M.; Blackburn, L.; Tchernof, A. Low abdominal subcutaneous preadipocyte adipogenesis is associated with visceral obesity, visceral adipocyte hypertrophy, and a dysmetabolic state. Adipocyte 2014, 3, 197-205. [CrossRef]

16. Gustafson, B.; Nerstedt, A.; Smith, U. Reduced subcutaneous adipogenesis in human hypertrophic obesity is linked to senescent precursor cells. Nat. Commun. 2019, 10, 2757. [CrossRef]

17. Gustafson, B.; Gogg, S.; Hedjazifar, S.; Jenndahl, L.; Hammarstedt, A.; Smith, U. Inflammation and impaired adipogenesis in hypertrophic obesity in man. Am. J. Physiol. Endocrinol. Metab. 2009, 297, E999-E1003. [CrossRef]

18. Isakson, P.; Hammarstedt, A.; Gustafson, B.; Smith, U. Impaired preadipocyte differentiation in human abdominal obesity: Role of Wnt, tumor necrosis factor-alpha, and inflammation. Diabetes 2009, 58, 1550-1557. [CrossRef]

19. Gustafson, B.; Hammarstedt, A.; Andersson, C.X.; Smith, U. Inflamed adipose tissue: A culprit underlying the metabolic syndrome and atherosclerosis. Arterioscler. Thromb. Vasc. Biol. 2007, 27, 2276-2283. [CrossRef]

20. Zuk, P.A.; Zhu, M.; Mizuno, H.; Huang, J.; Futrell, J.W.; Katz, A.J.; Benhaim, P.; Lorenz, H.P.; Hedrick, M.H. Multilineage cells from human adipose tissue: Implications for cell-based therapies. Tissue Eng. 2001, 7, 211-228. [CrossRef]

21. Zuk, P.A.; Zhu, M.; Ashjian, P.; De Ugarte, D.A.; Huang, J.I.; Mizuno, H.; Alfonso, Z.C.; Fraser, J.K.; Benhaim, P.; Hedrick, M.H. Human adipose tissue is a source of multipotent stem cells. Mol. Biol. Cell 2002, 13, 4279-4295. [CrossRef]

22. Falls, D.L. Neuregulins: Functions, forms, and signaling strategies. Exp. Cell Res. 2003, 284, 14-30. [CrossRef]

23. Mei, L.; Xiong, W.-C. Neuregulin 1 in neural development, synaptic plasticity and schizophrenia. Nat. Rev. Neurosci. 2008, 9, 437-452. [CrossRef] [PubMed]

24. Meyer, D.; Birchmeier, C. Multiple essential functions of neuregulin in development. Nature 1995, 378, 386-390. [CrossRef] [PubMed]

25. Kramer, R.; Bucay, N.; Kane, D.J.; Martin, L.E.; Tarpley, J.E.; Theill, L.E. Neuregulins with an Ig-like domain are essential for mouse myocardial and neuronal development. Proc. Natl. Acad. Sci. USA 1996, 93, 4833-4838. [CrossRef] [PubMed]

26. Guo, Y.; Cao, R.; Zhang, X.; Huang, L.; Sun, L.; Zhao, J.; Ma, J.; Han, C. Recent Progress in Rare Oncogenic Drivers and Targeted Therapy for Non-Small Cell Lung Cancer. Onco. Targets Ther. 2019, 12, 10343-10360. [CrossRef]

27. Trombetta, D.; Rossi, A.; Fabrizio, F.P.; Sparaneo, A.; Graziano, P.; Fazio, V.M.; Muscarella, L.A. NRG1-ErbB Lost in Translation: A New Paradigm for Lung Cancer? Curr. Med. Chem. 2017, 24, 4213-4228. [CrossRef]

28. Schmid, R.S.; McGrath, B.; Berechid, B.E.; Boyles, B.; Marchionni, M.; Sestan, N.; Anton, E.S. Neuregulin 1-erbB2 signaling is required for the establishment of radial glia and their transformation into astrocytes in cerebral cortex. Proc. Natl. Acad. Sci. USA 2003, 100, 4251-4256. [CrossRef]

29. Sato, T.; Sato, F.; Kamezaki, A.; Sakaguchi, K.; Tanigome, R.; Kawakami, K.; Sehara-Fujisawa, A. Neuregulin 1 Type II-ErbB Signaling Promotes Cell Divisions Generating Neurons from Neural Progenitor Cells in the Developing Zebrafish Brain. PLoS ONE 2015, 10, e0127360. [CrossRef]

30. Pirotte, D.; Wislet-Gendebien, S.; Cloes, J.M.; Rogister, B. Neuregulin-1 modulates the differentiation of neural stem cells in vitro trough an interaction with the Swi/Snf complex. Mol. Cell. Neurosci. 2010, 43, 72-80. [CrossRef] 
31. Bersell, K.; Arab, S.; Haring, B.; Kuhn, B. Neuregulin1/ErbB4 Signaling Induces Cardiomyocyte Proliferation and Repair of Heart Injury. Cell 2009, 138, 257-270. [CrossRef]

32. Wang, Z.; Xu, G.; Wu, Y.; Guan, Y.; Cui, L.; Lei, X.; Zhang, J.; Mou, L.; Sun, B.; Dai, Q. Neuregulin-1 enhances differentiation of cardiomyocytes from embryonic stem cells. Med. Biol. Eng. Comput. 2009, 47, 41-48. [CrossRef]

33. Díaz-Herráez, P.; Garbayo, E.; Simón-Yarza, T.; Formiga, F.R.; Prosper, F.; Blanco-Prieto, M.J. Adipose-derived stem cells combined with neuregulin-1 delivery systems for heart tissue engineering. Eur. J. Pharm. Biopharm. 2013, 85, 143-150. [CrossRef]

34. Liang, X.; Ding, Y.; Zhang, Y.; Chai, Y.-H.; He, J.; Chiu, S.-M.; Gao, F.; Tse, H.-F.; Lian, Q. Activation of NRG1-ERBB4 signaling potentiates mesenchymal stem cell-mediated myocardial repairs following myocardial infarction. Cell Death Dis. 2015, 6, e1765. [CrossRef] [PubMed]

35. Bruun, K.; Schermer, E.; Sivendra, A.; Valaik, E.; Wise, R.B.; Said, R.; Bracht, J.R. Therapeutic applications of adipose-derived stem cells in cardiovascular disease. Am. J. Stem Cells 2018, 7, 94-103. [PubMed]

36. Chua, Y.L.; Ito, Y.; Pole, J.C.M.; Newman, S.; Chin, S.-F.; Stein, R.C.; Ellis, I.O.; Caldas, C.; O’Hare, M.J.; Murrell, A.; et al. The NRG1 gene is frequently silenced by methylation in breast cancers and is a strong candidate for the 8p tumour suppressor gene. Oncogene 2009, 28, 4041-4052. [CrossRef] [PubMed]

37. Huang, H.-P.; Yu, C.-Y.; Chen, H.-F.; Chen, P.-H.; Chuang, C.-Y.; Lin, S.-J.; Huang, S.-T.; Chan, W.-H.; Ueng, T.-H.; Ho, H.-N.; et al. Factors from human embryonic stem cell-derived fibroblast-like cells promote topology-dependent hepatic differentiation in primate embryonic and induced pluripotent stem cells. J. Biol. Chem. 2010, 285, 33510-33519. [CrossRef]

38. Christian, M. Transcriptional fingerprinting of "browning" white fat identifies NRG4 as a novel adipokine. Adipocyte 2015, 4, 50-54. [CrossRef]

39. Paffhausen, E.S.; Ylowais, Y.; Chao, C.W.; Callihan, E.C.; Creswell, K.; Bracht, J.R. Discovery of a stem-like multipotent cell fate. Am. J. Stem Cells 2018, 7, 25-37.

40. Fleury, C.; Neverova, M.; Collins, S.; Raimbault, S.; Champigny, O.; Levi-Meyrueis, C.; Bouillaud, F.; Seldin, M.F.; Surwit, R.S.; Ricquier, D.; et al. Uncoupling protein-2: A novel gene linked to obesity and hyperinsulinemia. Nat. Genet. 1997, 15, 269-272. [CrossRef]

41. Pecqueur, C.; Alves-Guerra, M.C.; Gelly, C.; Levi-Meyrueis, C.; Couplan, E.; Collins, S.; Ricquier, D.; Bouillaud, F.; Miroux, B. Uncoupling protein 2, in vivo distribution, induction upon oxidative stress, and evidence for translational regulation. J. Biol. Chem. 2001, 276, 8705-8712. [CrossRef] [PubMed]

42. Nascimento, E.B.M.; Sparks, L.M.; Divoux, A.; van Gisbergen, M.W.; Broeders, E.P.M.; Jörgensen, J.A.; Schaart, G.; Bouvy, N.D.; van Marken Lichtenbelt, W.D.; Schrauwen, P. Genetic Markers of Brown Adipose Tissue Identity and In Vitro Brown Adipose Tissue Activity in Humans. Obesity 2018, 26, 135-140. [CrossRef] [PubMed]

43. Lee, K.Y.; Luong, Q.; Sharma, R.; Dreyfuss, J.M.; Ussar, S.; Kahn, C.R. Developmental and functional heterogeneity of white adipocytes within a single fat depot. EMBO J. 2019, 38, e99291. [CrossRef] [PubMed]

44. Kwan, R.; Looi, K.; Omary, M.B. Absence of keratins 8 and 18 in rodent epithelial cell lines associates with keratin gene mutation and DNA methylation: Cell line selective effects on cell invasion. Exp. Cell Res. 2015, 335, 12-22. [CrossRef]

45. Ferrario, C.; Lavagni, P.; Gariboldi, M.; Miranda, C.; Losa, M.; Cleris, L.; Formelli, F.; Pilotti, S.; Pierotti, M.A.; Greco, A. Metallothionein $1 \mathrm{G}$ acts as an oncosupressor in papillary thyroid carcinoma. Lab. Invest. 2008, 88, 474-481. [CrossRef]

46. Giri, A.K.; Aittokallio, T. DNMT Inhibitors Increase Methylation in the Cancer Genome. Front. Pharmacol. 2019, 10, 385. [CrossRef] [PubMed]

47. Gao, R.; Zhang, J.; Cheng, L.; Wu, X.; Dong, W.; Yang, X.; Li, T.; Liu, X.; Xu, Y.; Li, X.; et al. A Phase II, randomized, double-blind, multicenter, based on standard therapy, placebo-controlled study of the efficacy and safety of recombinant human neuregulin-1 in patients with chronic heart failure. J. Am. Coll. Cardiol. 2010, 55, 1907-1914. [CrossRef]

48. Jabbour, A.; Hayward, C.S.; Keogh, A.M.; Kotlyar, E.; McCrohon, J.A.; England, J.F.; Amor, R.; Liu, X.; Li, X.Y.; Zhou, M.D.; et al. Parenteral administration of recombinant human neuregulin-1 to patients with stable chronic heart failure produces favourable acute and chronic haemodynamic responses. Eur. J. Heart Fail. 2011, 13, 83-92. [CrossRef] 
49. Ennequin, G.; Boisseau, N.; Caillaud, K.; Chavanelle, V.; Etienne, M.; Li, X.; Montaurier, C.; Sirvent, P. Neuregulin 1 affects leptin levels, food intake and weight gain in normal-weight, but not obese, $\mathrm{db} / \mathrm{db}$ mice. Diabetes Metab. 2015, 41, 168-172. [CrossRef]

50. Vandekerckhove, L.; Vermeulen, Z.; Liu, Z.Z.; Boimvaser, S.; Patzak, A.; Segers, V.F.M.; De Keulenaer, G.W. Neuregulin-1 attenuates development of nephropathy in a type 1 diabetes mouse model with high cardiovascular risk. Am. J. Physiol. Endocrinol. Metab. 2016, 310, E495-E504. [CrossRef]

51. Ennequin, G.; Boisseau, N.; Caillaud, K.; Chavanelle, V.; Etienne, M.; Li, X.; Sirvent, P. Neuregulin 1 Improves Glucose Tolerance in db/db Mice. PLoS ONE 2015, 10, e0130568. [CrossRef] [PubMed]

52. Caillaud, K.; Boisseau, N.; Ennequin, G.; Chavanelle, V.; Etienne, M.; Li, X.; Denis, P.; Dardevet, D.; Lacampagne, A.; Sirvent, P. Neuregulin 1 improves glucose tolerance in adult and old rats. Diabetes Metab. 2016, 42, 96-104. [CrossRef] [PubMed]

53. Snodgrass-Belt, P.; Gilbert, J.L.; Davis, F.C. Central administration of transforming growth factor-alpha and neuregulin-1 suppress active behaviors and cause weight loss in hamsters. Brain Res. 2005, 1038, 171-182. [CrossRef] [PubMed]

54. Heal, D.J.; Smith, S.L.; Jones, R.B. Central regulation of food intake and energy expenditure. Neuropharmacology 2012, 63, 1-2. [CrossRef]

55. Geisberg, C.A.; Wang, G.; Safa, R.N.; Smith, H.M.; Anderson, B.; Peng, X.Y.; Veerkamp, B.; Zhao, D.X.; Blakemore, D.; Yu, C.; et al. Circulating neuregulin-1beta levels vary according to the angiographic severity of coronary artery disease and ischemia. Coron. Artery Dis. 2011, 22, 577-582. [CrossRef]

56. Moondra, V.; Sarma, S.; Buxton, T.; Safa, R.; Cote, G.; Storer, T.; Lebrasseur, N.K.; Sawyer, D.B. Serum Neuregulin-1beta as a Biomarker of Cardiovascular Fitness. Open Biomark. J. 2009, 2, 1-5. [CrossRef]

57. Galvez-Contreras, A.Y.; Quiñones-Hinojosa, A.; Gonzalez-Perez, O. The role of EGFR and ErbB family related proteins in the oligodendrocyte specification in germinal niches of the adult mammalian brain. Front. Cell. Neurosci. 2013, 7, 258. [CrossRef]

58. Pareja, F.; Pines, G.; Yarden, Y. Receptor Tyrosine Kinases: Family and Subfamilies. In The EGFR/ERBB Receptor Family; Wheeler, D., Yarden, Y., Eds.; Springer: Basel, Switzerland, 2015; pp. 107-164.

59. Locke, A.E.; Kahali, B.; Berndt, S.I.; Justice, A.E.; Pers, T.H.; Day, F.R.; Powell, C.; Vedantam, S.; Buchkovich, M.L.; Yang, J.; et al. Genetic studies of body mass index yield new insights for obesity biology. Nature 2015, 518, 197-206. [CrossRef]

60. Sandholm, N.; Salem, R.M.; McKnight, A.J.; Brennan, E.P.; Forsblom, C.; Isakova, T.; McKay, G.J.; Williams, W.W.; Sadlier, D.M.; Mäkinen, V.-P.; et al. New susceptibility loci associated with kidney disease in type 1 diabetes. PLoS Genet. 2012, 8, e1002921. [CrossRef]

61. Böger, C.A.; Sedor, J.R. GWAS of diabetic nephropathy: Is the GENIE out of the bottle? PLoS Genet. 2012, 8, e1002989. [CrossRef]

62. Dekker, J.; Mirny, L. The 3D Genome as Moderator of Chromosomal Communication. Cell 2016, 164, 1110-1121. [CrossRef] [PubMed]

63. Todaro, G.J.; Green, H. Quantitative studies of the growth of mouse embryo cells in culture and their development into established lines. J. Cell Biol. 1963, 17, 299-313. [CrossRef] [PubMed]

64. Chen, Y.-S.; Wu, R.; Yang, X.; Kou, S.; MacDougald, O.A.; Yu, L.; Shi, H.; Xue, B. Inhibiting DNA methylation switches adipogenesis to osteoblastogenesis by activating Wnt10a. Sci. Rep. 2016, 6, 25283. [CrossRef] [PubMed]

65. Yang, X.; Wu, R.; Shan, W.; Yu, L.; Xue, B.; Shi, H. DNA Methylation Biphasically Regulates 3T3-L1 Preadipocyte Differentiation. Mol. Endocrinol. 2016, 30, 677-687. [CrossRef]

66. Mazzu, Y.Z.; Hu, Y.; Soni, R.K.; Mojica, K.M.; Qin, L.-X.; Agius, P.; Waxman, Z.M.; Mihailovic, A.; Socci, N.D.; Hendrickson, R.C.; et al. miR-193b-Regulated Signaling Networks Serve as Tumor Suppressors in Liposarcoma and Promote Adipogenesis in Adipose-Derived Stem Cells. Cancer Res. 2017, 77, 5728-5740. [CrossRef]

67. Zych, J.; Stimamiglio, M.A.; Senegaglia, A.C.; Brofman, P.R.S.; Dallagiovanna, B.; Goldenberg, S.; Correa, A. The epigenetic modifiers 5-aza-2'-deoxycytidine and trichostatin A influence adipocyte differentiation in human mesenchymal stem cells. Braz. J. Med. Biol. Res. 2013, 46, 405-416. [CrossRef]

68. Bracht, J.R.; Vieira-Potter, V.; de Souza Santos, R.; Oz, O.; Palmer, B.; Clegg, D. The Role of Estrogens in the Adipose Tissue Milieu. Ann. N. Y. Acad. Sci. 2019, 1641, 127-143. [CrossRef] 
69. van den Dungen, M.W.; Murk, A.J.; Kok, D.E.; Steegenga, W.T. Comprehensive DNA Methylation and Gene Expression Profiling in Differentiating Human Adipocytes. J. Cell. Biochem. 2016, 117, 2707-2718. [CrossRef]

70. Zaim, M.; Karaman, S.; Cetin, G.; Isik, S. Donor age and long-term culture affect differentiation and proliferation of human bone marrow mesenchymal stem cells. Ann. Hematol. 2012, 91, 1175-1186. [CrossRef]

71. Zhang, P.; Kuang, H.; He, Y.; Idiga, S.O.; Li, S.; Chen, Z.; Yang, Z.; Cai, X.; Zhang, K.; Potthoff, M.J.; et al. NRG1-Fc improves metabolic health via dual hepatic and central action. JCI Insight 2018, 3, 98522. [CrossRef]

72. Ennequin, G.; Capel, F.; Caillaud, K.; Chavanelle, V.; Etienne, M.; Teixeira, A.; Li, X.; Boisseau, N.; Sirvent, P. Neuregulin 1 improves complex 2-mediated mitochondrial respiration in skeletal muscle of healthy and diabetic mice. Sci. Rep. 2017, 7, 1742. [CrossRef] [PubMed]

(C) 2020 by the authors. Licensee MDPI, Basel, Switzerland. This article is an open access article distributed under the terms and conditions of the Creative Commons Attribution (CC BY) license (http://creativecommons.org/licenses/by/4.0/). 